Document downloaded from:

http://hdl.handle.net/10251/117896

This paper must be cited as:

Moreno, JD.; Pellicer, TM.; Adam, JM.; Bonilla Salvador, MM. (2018). Exposure of RC building structures to the marine environment of the Valencia coast. Journal of Building Engineering. 15:109-121. https://doi.org/10.1016/j.jobe.2017.11.016

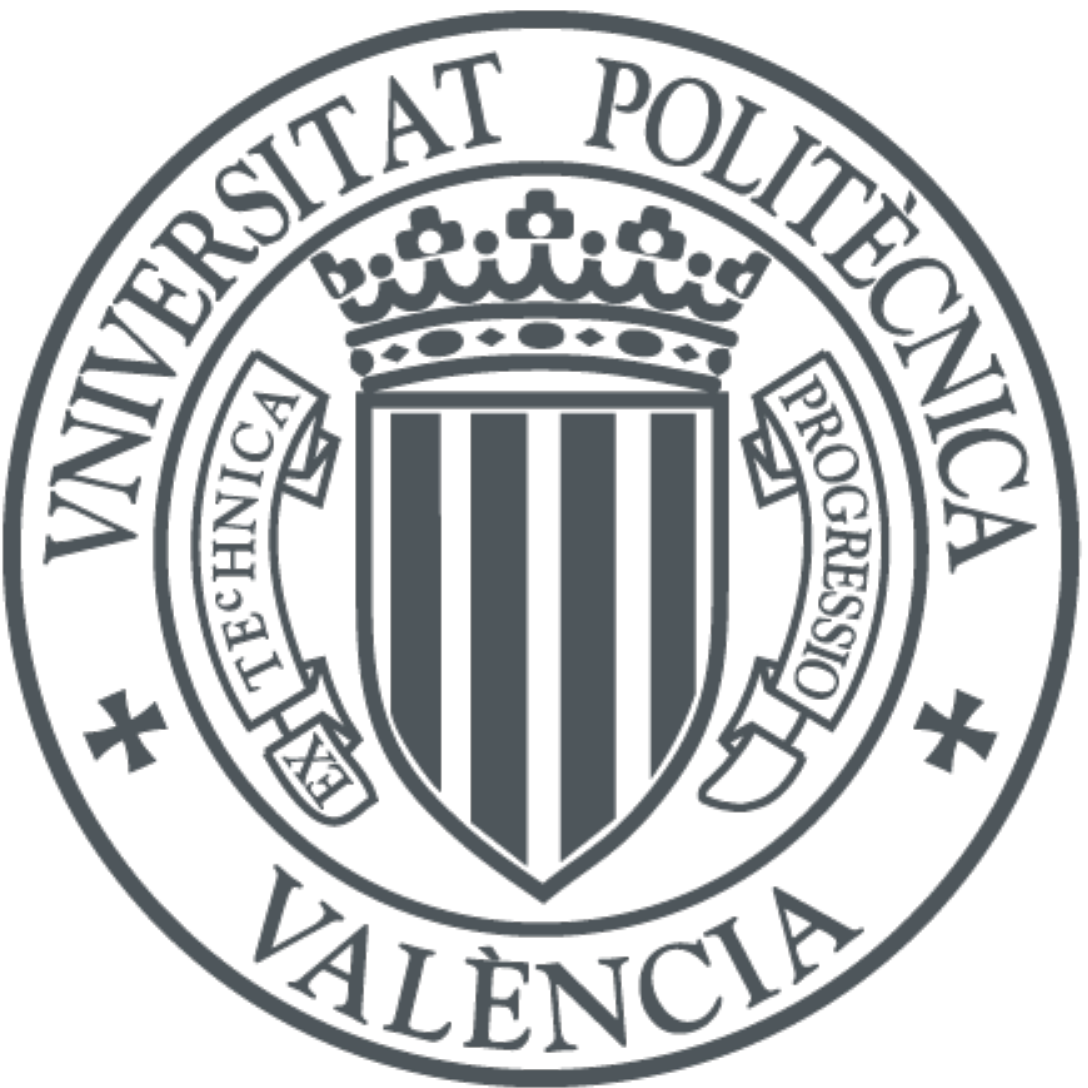

The final publication is available at

http://doi.org/10.1016/j.jobe.2017.11.016

Copyright Elsevier

Additional Information 


\title{
Exposure of RC building structures to marine environment
}

\author{
Jose D. Moreno, Teresa M. Pellicer, Jose M. Adam*, Mercedes Bonilla \\ ICITECH, UniversitatPolitècnica de València, Valencia, Spain \\ *Corresponding author.E-mail address: joadmar@upv.es
}

\begin{abstract}
As the marine atmosphere is very harmful to reinforced concrete (RC) structures, buildings situated close to the sea are at a high risk of suffering damage. Such is the case of many of the buildings near the coast in Valencia (Spain). Most of these buildings were built between 1968 and 2007 and nowadays their RC structures are seriously damaged. This paper describes the condition of 1816 buildings that were inspected in 14 towns placed in Valencia coast. From these inspections, there have been identified the main factors which are the most significant in the damage of these RC structures by the aggressive marine conditions. These factors include environmental characteristics, urban parameters and construction system of the buildings.
\end{abstract}

Keywords: building failure; concrete; durability; repair; chloride attack; marine environment; corrosion

\section{Introduction}

The marine environment is highly aggressive to $\mathrm{RC}$ structures and it has a considerable effect on their service life. Serious damage is thus often found in building structures near the sea. This is even worse if no special protection has been given to these structures, or if there not were paid attention to this aspect during their construction. In a previous study, Adam et al. [1] analysed the types of damage found in RC building structures close to the sea by inspecting 1816 buildings in 14 towns on the Valencia coast. Based on the information obtained from this study, the present paper analyses the factors that have major influence on the exposure to aggressive environment of the buildings.

The territorial context predetermines the construction system according to the 
characteristics of the soil and the surroundings. The appropriate building construction system should be selected for each location taking into account those aspects. However, this has never been the traditional practice. In most cases, especially in holiday resorts, the factors governing the selection of building typology are mainly economics, not technical. That means giving no consideration to durability aspects as the RC building structure protection to marine environment. This has occurred especially in coastal areas in which the population growth has been uncontrolled and, in most cases, without an adequate city planning.

Such has been the case of many buildings constructed on the coast of Valencia (Spain). This region, bathed by the Mediterranean Sea has undergone a profound metamorphosis in the last 50 years, becoming a popular area for holiday homes [2]. Since the late sixties, it has experienced a continual growth in tourism which has greatly multiplied the number of buildings constructed in the area, especially of those that could be described as weekend or holiday homes. This effect was increased during the periods of the building expansion as occurred between 1968 and 1973.

In the coastal towns, the population increases considerably during the holiday periods, and in some cases may even be doubled, as in Benidorm, Torrevieja, Calpe, Denia, Santa Pola, Orihuela, Jávea, Cullera, Gandía, Benicàssim, Oropesa del Mar and Peñíscola, where the number of holiday homes is greater than those used as habitual residences [3].

The building typology used in these areas is the apartment block (Fig. 1a), although there are also many terraced houses (Fig. 1b). The structure of the buildings is usually made with RC frames and generally precast joist slabs. The RC structure is often visible 
(mainly on outer walls and open-plan ground floors) or given a thin covering of mortar [4]. These buildings are therefore highly exposed to the aggressive agents in the marine atmosphere [1].

The corrosion of the reinforcement by the sea atmosphere is one of the main causes of the deterioration of $\mathrm{RC}[5,6]$. There is a large bibliography on the general factors that affect $\mathrm{RC}$ structures in a marine atmosphere $[7,8]$ and the reinforcement corrosion by chloride $[9,10]$. The present study analyses the factors that determine the influence of the marine environment on coastal buildings. It focuses on the apartment blocks in 14 towns of Valencia (see Fig. 2). They are, from north to south: Peñíscola, Torreblanca, Oropesa del Mar, Benicàssim, Moncofa, El Puig, Pobla de Farnals, Port Saplaya, El Perellonet, Cullera, Tavernes de la Valldigna, Xeraco, Calpe and Playa de San Juan. These areas were not chosen at random; on the contrary, they were considered to be representative of the buildings along the Valencia coast, as has been shown in Adam et al. [1].

The principal novelty of the work therefore lies in the selection and analysis of the variables that determine the influence of the marine atmosphere on $\mathrm{RC}$ building structures. The studied variables were as follows:

(1) Climatology: temperature, humidity, prevailing winds.

(2) Planning: distance from the sea, urban morphology, urban growth.

(3) Structures: codes applied, concrete characteristics, construction system.

The paper is organised into six sections, starting with Section 1 or Introduction. Section 2 describes the effects of the aggressive marine atmosphere and its effects on RC structures. Section 3 describes the Valencia coastline and its RC building structures. It 
also describes the climatology and the orography of its towns, the urban growth and the buildings typologies. Section 4 analyses the characteristics of the buildings studied, including their structural and construction system. Section 5 analyses the particular variables that determine the degree of exposure of the buildings to the marine atmosphere. Finally, Section 6 presents the conclusions reached in the work and the future lines of research.

\section{Influence of the marine atmosphere on RC building structures}

The principal damage to $\mathrm{RC}$ in marine atmospheres is the corrosion of the reinforcement by chlorides [6,7]. This is due to the high content of chloride ions and salts together with a high moisture content, which accentuates their effects. This has been corroborated by Moreno et al. [4] in the study of RC building structures in Valencia coast whose reinforcement was corroded due to the considerable presence of chloride ions. However, other aggressive components as the magnesium sulphate are also damaging to these structures $[11,12]$.

Although damage by chloride ions is the quickest acting, it is not the only cause of corroded reinforcement. The process may be combined and accelerated by concrete carbonation when the air has high moisture content $[8,13]$. However, it has been shown that the contact of aggressive agents with the reinforcement is the fundamental factor in its corrosion and it directly affects its service life $[5,10,14,15,16$,$] . According to these$ authors, the internal factors that have most influence on the penetration of aggressive agents are the concrete's resistivity, permeability and porosity. Particularly, in hot and humid coastal environments the problem increases [17].

The behaviour of RC against aggressive agents is determined by its quality, which 
depends basically on the type of cement used, the water/cement ratio, the cement covering of the reinforcement and the type of steel used. These characteristics are determined by the concrete quality $[10,7]$ what depends largely on the period in which the building was constructed, the codes in force at the time, the construction methods used, or in other words, on the age of the building. The age of the structure is not only fundamental in determining its physical condition but also in knowing the building tradition and the technology in use at the time.

Other factors that affect the corrosion of reinforcement and that do not depend on the type of concrete include: the salt content of the atmosphere, the degree of exposure of the structure to the environment (e.g. the prevailing winds), the situation of the structure (inside or outside the building) and the moisture present in the concrete pores $[5,7,18-$ 20]. The most important of these are as follows:

(1) Distance from the sea is one determining factor in the quantity of salt particles in the air. The salinity depends on the distance from the sea water line and is rapidly reduced with distance from this mark. Different authors [18,19] have shown that the concentration of chloride ions in the atmosphere decrease rapidly with distance from the coast, especially in the first $100 \mathrm{~m}$ [19], after which the concentration reduction rate is slower.

(2) The orography and the speed of the prevailing winds [18,20,21] has also an important influence in the salt content of the air. Morcillo et al. [22] in a study on the coast of Tarragona (Spain) determined atmospheric salinity by analysing the winds recorded by the meteorological stations. They found that certain directions of the prevailing wind contribute most to the inland penetration of salt 
particles. The wind speed is also important, since above $3 \mathrm{~m} / \mathrm{s}(10.80 \mathrm{~km} / \mathrm{h})$ the formation of the salt spray phenomenon begins to be significant [22,23].

(3) Relative humidity has a decisive influence on the degree of exposure to the sea atmosphere. Zaccardi et al. [24] have studied the influence of ambient temperature and relative humidity in the corrosion of reinforcing bars in $\mathrm{RC}$ structures in a marine environment. Bouteiller et al. [25] demonstrated that temperature and humidity interact with each other in the corrosion processes. Karthick et al. [26] indicate that the carbonatation of concrete and the penetration of chloride ions are the most influent factors in the depassivation of the reinforcement. Sandberg et al. [27] have shown that when the passivity of the reinforcement has been broken by the presence of chloride ions, concrete resistivity is the parameter that controls the corrosion kinetics. In this case, the moisture content in the pores plays a determining role and is considered the most influential variable in concrete resistivity $[15,27]$. However, relative humidity also depends greatly on the atmospheric wetting-drying cycles [28]. Medeiros et al. [29] studied the behaviour of a structure exposed to the marine atmosphere for 40 years. This study showed that the wetting-drying cycles to which the structure is exposed have influence in its chloride ion content, and the rainfall pattern is decisive in these cycles. Other authors [22] have verified that there are high levels of atmospheric salt content after storms. These atmospheric phenomena, even though they last for a short time, can leave large quantities of salt on concrete surfaces.

(4) The urban growth type in a town is also significant when analysing the influence of the marine atmosphere on its buildings. For example, in places where 
buildings are very close together, those that are exposed can act as windbreak to others, which are thus protected. On the one hand, there are perimeter blocks (which are built up on all sides surrounding a semi-private central space) that have smaller exposed surfaces, but some of them are more exposed than the others. On the other hand, there are apartment blocks (residential high-rise buildings) that are exposed on all sides, allowing the salt spray to circulate freely with nothing to act as a barrier. In this type, different zones of the buildings will be more affected than others and to different degrees.

\section{Urban development on the Valencia coastline}

The study carried out was focused on Valencia region (Fig. 3), in the Mediterranean coast of Spain. In this coastline, which is $440 \mathrm{~km}$ long, there are 62 towns with a large number of holiday homes, mostly built between 1968 and 2007. In these years the coastal areas changed their principal use, from flat wetlands covered with vegetation without any use or used for agriculture to holiday resorts. Therefore, these areas evolved from dispersed settlements to urban areas without a previous master plan [2].

This change in pattern had its origin in the 1956 Land Use and Urban Planning Law [30]. The purpose of it was to develop the coast by building holiday apartments and hotels. In this way, tourism became the motor of the Spanish economy, especially in the coastal areas and in particular on the Mediterranean coast. In this area the development was massive, multiplying the number of buildings and the population, especially in the

summer season [2]. The consequence of this unplanned urban growth was the disproportionate increase of the buildings in the coastline.

Throughout this period the urban development was based on a model with high density 
areas and high-rise apartment blocks whose ground floors were in most cases unoccupied. The absence of an urban planning with specific regulations and the rapid rate of construction gave rise to a similar type of buildings in terms of shape, composition and construction. This model faithfully followed a common plan: apartment blocks or single family houses on different sized plots, close to the beach and separated by a road in between [31].

This uncontrolled urban growth on the coast occurred without having into consideration how to protect the buildings from the marine atmosphere. Consequently, nowadays a high proportion of these $\mathrm{RC}$ building structures present damage as a result of the corrosion of the reinforcement bars, as has been pointed out by [5,7]. This damage is concentrated in the parts of the structures most exposed to the air [1], such as columns, fronts of slabs, ledges and balcony beams (Fig. 4).

\section{Characteristics of residential buildings on the Valencia coast}

The structural characteristics of the buildings studied can be related to the different periods of economic expansion and crisis of the Spanish construction industry, and in particular on the Valencia coast:

(1) First period: 1968-1973, the first period of expansion of the building industry.

(2) Second period: 1973-1985, beginning with the oil crisis in 1973 and lasted until the beginning of the next economic recovery.

(3) Third period: 1985-1992, consisted of the second period of the expansion of the industry.

(4) Fourth period: 1992-1997, it began with the economic crisis in 1992 and was shorter than the previous ones, lasting for approximately 5 years. 
(5) Fifth period: 1997-2007, it was the third period of expansion and lasted until the start of the present economic crisis.

\subsection{Types of structural systems}

RC frame structures was used in $74.3 \%$ of the apartment blocks built in Valencia between 1960 and 1990, according to the inspection reports of the Office of Architecture and Housing of the Valencia Government (Dirección General de Arquitectura y Vivienda, DGA) [32]. The reports also indicate that a high percentage of those built more recently (1999-2005) in this area also have RC structures. It should be pointed out that "RC structures" here means the buildings basic structure, composed of $\mathrm{RC}$ frames and one-way or two-way slabs. Structural steel is not often used in this type of building and is only present in few cases (Fig. 5 [33]).

This study therefore confirms the predominance of RC framed structures. And this was also checked in the course of the 1816 buildings inspection in the 14 towns selected for the study. A high percentage of this type is found everywhere except for a small number of areas, according to this study.

As regards the characteristics of the RC frames, the use of wide flat beams depended on the period in which the building was constructed. Between 1968-1973 and 1973-1985, the first two periods considered, the use of wide flat beams was not very common. The use of them mainly depends on the tradition followed in the area in question (for instance, in the central region of Valencia there is no use of wide flat beams).

In the inspections carried out by Adam et al. [1] and also in the reports of the DGA [32], the one-way slab was the most frequently used. In more than half of the cases, the use of 
precast or pre-stressed RC joists predominated.

\subsection{Construction system of outer and inner walls}

The usual construction system consists on wet trades and heavyweight construction, with all the outer and inner walls built in situ (partitions, outer walls, insulations and coatings etc.). During the inspections carried out it was observed that the number of light outer walls and modular construction systems was quite small, less than $10 \%$.

Outer walls are usually made of two layers of hollow brick, forming an air chamber with or without insulating material. They are supported on the concrete structure; the outer layer is aligned with the surface defined by the front of the slab, or the edge of the slab is embedded in the outer wall. The front of the slab is usually covered by a thin mortar rendering or by 2 or $3 \mathrm{~cm}$ thick ceramic tiles. The presence of thermal insulation in the air chamber basically depends on the year of construction. It is not often found due to the mild climate in the region and the date of construction of these buildings.

The cladding of the outer walls is usually a single coat of mortar (Fig. 6a) or painted cement-mortar rendering. In some cases, the structure is visible on the walls and/or on ground floors (Fig. 6b), especially in those of the second and third periods studied (1973-1985 and1985-1992).

\subsection{Dosage, strength and covering of $R C$}

As regards the characteristics of the concrete, there are wide variations in the dosage due to the absence of quality control requirements in the first Spanish concrete codes: HA-61 [34], HA-68 [35] and EH-73 [36]. These codes did not require previous tests but relied on the builders' previous experience: "In cases in which the builder can justify by 
previous experience that the selected materials, dosage and execution process will produce concrete with the above-mentioned conditions, in particular in the required strength, the preliminary tests may be dispensed with" (HA-68 [35], p. 17262). This system was in force until the introduction of EH-88 [37] and is far removed from the present quality control criteria.

In the structures built during the first period studied (1968-1973), the concrete strength was given by concrete dosage established by the codes. These dosages were specified in the form of tables included in the Appendices to EH-61 [34], EH-68 [35] and EH-73 [36]. In these tables the quantities of the concrete components were determined by the characteristic strength required, the type and the maximum size of the aggregates, the type of cement and the degree of compaction. These codes also left the protection measures against aggressive atmospheres to the builder's decision: "In structures exposed to chemically aggressive atmospheres or to the risk of fires, the covering of the reinforcement will be decided by the person responsible for the project" (HA-68 [35], Art. 13.3.c, p. 17262). Minimum general reinforcement covering was proposed, but no specific measures were given or recommended for structures exposed to marine atmospheres. For this reason, in the projects belonging to the first study period (19681973) the minimum covering specified was $30 \mathrm{~mm}$ or less.

The classes of exposure to different types of atmosphere and the minimum covering for each one were laid down in EH-88 [37] (Art. 13.3.b, p. 23263). It was also indicated: "In structures exposed to especially aggressive atmospheres, the project director will select the covering while bearing in mind that the above values should be prudently increased and that the compaction and non-porosity of the concrete should be carefully 
considered" (EH-88 [37], Art. 13.3.d, p. 23263).

\section{Exposure level of buildings to marine atmosphere}

As pointed out in Section 1, in order to analyse the exposure level of the buildings to the marine atmosphere the following variables were selected:

(1) Prevailing winds.

(2) Temperature and rainfall.

(3) Distance from the coast.

(4) Distance from the water line.

(5) Year of construction of building.

(6) Urban growth types.

\subsection{Characterisation of prevailing winds}

As indicated in Section 2, certain directions of the prevailing winds tend to generate high concentrations of salts in the air. It is therefore necessary to identify both the prevailing winds and their seasonal evolution to determine the buildings' exposure.

For this analysis, data supplied by the National Meteorological Agency (Agencia Nacional de Meteorología, AEMET) [38] was used, selecting the annual figures from the weather stations closest to the area analysed. The results obtained are given in Table 1, including the prevailing wind component and the mean wind speed in this direction in $\mathrm{km} / \mathrm{h}$. Although there were seasonal variations in these winds, it was possible to obtain an overall view of the directions of the prevailing winds and the most exposed zones and buildings. 
The prevailing wind was seen to have an eastern component, i.e. from the sea, with some variations, in most of the towns. However, in the particular case of Calpe, due to its location, the wind from the sea had a southern component.

As mentioned in Section 2, wind speed must also be taken into consideration, as above $10.80 \mathrm{~km} / \mathrm{h}$ the salt concentration is high. With this speed as the limit, the areas in the north of Valencia (Moncofa, Torreblanca and Oropesa del Mar), where the mean wind speed is $11.00 \mathrm{~km} / \mathrm{h}$, have high levels of exposure. The areas of Peñíscola, Pobla de Farnals, Port Saplaya and Calpe, with a mean speed close to the limit of around 10.00 $\mathrm{km} / \mathrm{h}$, are also highly exposed.

In the centre of the area, Cullera, Tavernes de la Valldigna and Xeraco, as well as La Playa de San Juan in Alicante, with a mean wind speed below the limit of $9.00 \mathrm{~km} / \mathrm{h}$, are less exposed. Due to the dispersion of these results it is not possible to group the towns into geographical zones, which means it would be necessary to study the orographic characteristics of their environments in relation to the prevailing winds, which is outside the scope of the present study.

\subsection{Temperature regime, relative humidity and rainfall}

As pointed out in Section 2, there are other factors affecting corrosion in reinforcement that exist irrespective of the type of concrete, such as temperatures and precipitation, which determine the moisture content of the concrete.

The study of the temperature regime was carried out based on data obtained from the historical series compiled by the Valencia Agrarian Research Institute (Instituto Valenciano de Investigaciones Agrarias, IVIA) [39], the State Meteorology Agency 
(Agencia Estatal de Meteorología, AEMET) [38] and the Climatic Atlas of Valencia Community [40]. By using these data, the mean temperature is shown by month for the studied towns in Fig. 7 and it is arranged in accordance with the meteorological station consulted. Accordingly, the temperature variability over the year was calculated in each case as the difference between the highest and the lowest temperatures. The temperature range has been shown to be very similar in all the areas studied, which is a result of the thermo-regulating effect of the Mediterranean Sea.

The temperature variability over the year does not usually exceed $14-15^{\circ} \mathrm{C}$, and the annual average temperature in the studied towns is from $16^{\circ} \mathrm{C}$ to $18^{\circ} \mathrm{C}$. The temperature on the Valencia coastline therefore shows little variation and stays within a median range of values that is not a determining factor in the rate of corrosion [28].

On the other hand, the relative humidity of the environment does affect the concrete's wetting-drying cycle, which is a critical factor in determining the degree of exposure to the sea environment. The precipitation regime on the Valencia coastline was therefore studied [41] and four different zones were chosen (Fig. 8):

(1) Zone 1 covers the areas situated in the north of the Valencia coast where annual precipitation is around $500-600 \mathrm{l} / \mathrm{m}^{2}$.

(2) Zone 2 is formed by the central flatlands in the north and centre of the Valencia coast, in which annual precipitation is somewhat lower, 400-500 1/ $\mathrm{m}^{2}$. In this zone the main maximum is in autumn, with another smaller maximum in spring, and a long dry summer period lasting around 4 months.

(3) Zone 3 stretches across the centre-south and is the rainiest, with annual precipitation of $600-800 \mathrm{l} / \mathrm{m}^{2}$. This is a result of the orientation of its coastline, 
which is almost perpendicular to the winds, which makes it liable to experience torrential downpours.

Zone 4 is in the south of Valencia coast. The average annual temperature is $18^{\circ} \mathrm{C}$ and the precipitation very low (in some towns not exceeding $300 \mathrm{l} / \mathrm{m}^{2}$ per year).

Based on the data obtained from the historical series from AEMET [38] graphs with the precipitation regimes of the selected towns are shown in Fig. 9. These graphs have a similar form, with a significant increase in precipitation in the months from August to October. There is however an important difference in total precipitation between the different towns.

In the towns located in the central zone of the Valencia coastline, such as Tavernes de la Valldigna, Xeraco, El Perellonet and Cullera, greater precipitation occurs in September and October, and exceeds $100 \mathrm{~mm}$ in each of these months. It is the same in Peñíscola, but in the town of Playa de San Juan the precipitation is less than $50 \mathrm{~mm}$ in those months. In April and May, Peñíscola gets higher precipitation (around $75 \mathrm{~mm}$ ). In contrast, La Playa de San Juan only gets about $30 \mathrm{~mm}$.

This increase in precipitation is a result of the habitual Mediterranean storms at the end of the summer months and above all in autumn. These storms provide around $50 \%$ of the annual rainfall in those very short periods of time.

\subsection{Distance of the buildings from the sea}

The Spanish Coastal Law [42] in Article 23.1 (p. 13) stipulates that "the easement of coast protection shall apply to a zone of 100 metres measured inland from the sea limit". Article 25.1.a (p. 14) points out that within this area "buildings for residence and 
dwelling" are prohibited. However, many towns Valencia coast have buildings at a shorter distance from the coast, as they were built before the above-mentioned law was enacted. In many cases, the distance from the buildings to the sea is below the 100 metre limit, which is the distance at which there is a significant reduction in the concentration of chloride ions in the atmosphere, as has been pointed out in Section 2. It is, therefore, necessary to calculate the buildings' degree of exposure to the marine environment in accordance with their distance from the seashore. To do this, three different strips were selected:

(1) Distance to the seashore of between 0 and 50 metres.

(2) Distance to the seashore of between 50 and 100 metres.

(3) Distances above 100 metres.

As the next step, the buildings were classified according to the strip they occupy. To work out how far they are from the seashore, the distance was measured from a point in the centre of the side of the building nearest to the sea. The result is displayed in Fig. 10 , shown by percentage and by town.

It can be seen that in some towns such as Peñíscola, Oropesa del Mar, Cullera and Calpe there is a high proportion of buildings at a distance of less than $50 \mathrm{~m}$ from the seashore, in Peñíscola over 25\% and in Calpe over 15\%. Such urban areas are generally found in zones where there is no proper beach as such, or, if there is, it is very small, and these areas are typical of urban developments in mountainous areas. The degree of exposure of the buildings situated in this first strip is high.

The second strip, between 50 and 100 metres from the seashore, is a zone with a high level of exposure. This is the case of the towns of Peñíscola, Torreblanca, Port Saplaya 
and el Perellonet, which have over 30\% of their buildings situated in this strip.

In contrast, in other towns all the blocks of flats are more than 100 metres from the seashore, as is the case of El Puig, Pobla de Farnals and Playa de San Juan. This is due to the existence of beaches with large areas of sand and to their promenades (Playa de San Juan), and above all, to the existence of houses or non-residential buildings situated on the beach (El Puig and Pobla de Farnals). The degree of exposure of the buildings situated in this strip is lower than for the cases above mentioned.

\subsection{Location of the buildings with respect to the sea coast}

In residential areas with several rows of houses, the degree of exposure is greater on the row situated nearest the beach than for the second line and others further back. This is because of the windbreak effect created by the buildings (Fig. 11 [43]). For this reason the towns have been classified in accordance with the location of their apartment blocks as:

- Buildings on the front line of the beach.

- Buildings on the second and other lines further back.

As can be seen in Fig. 12, there are towns such as Peñíscola, Torreblanca and Port Saplaya with a high proportion of buildings blocks on the front line (between $60 \%$ and 70\%). In contrast, in Moncofa, el Puig and Playa de San Juan, the percentage of apartment blocks located on the second line is nearly $100 \%$. In the case of Pobla de Farnals, it is $100 \%$. This high level is due to the existence of single-dwellings or nonresidential buildings (usually restaurants, bars or other leisure facilities) on the front line, as pointed out above. 
Buildings of the type under study, i.e. apartment blocks, are normally oriented towards the sea, so as to take advantage of the views and the sea breeze. They are usually of more than 10 storeys, with multiple terraces, balconies, large verandas, and accessible flat-roof areas, ground floors having few partition walls and sometimes being even totally open and therefore supported by free-standing columns.

\subsection{Age of the buildings}

The age of the buildings is another factor that needs to be taken into account in determining the buildings' degree of exposure to the marine environment, for two reasons: firstly, because the age determines the time in which they were built and its consequent characteristics (the codes in force, the characteristics of the concrete, the cladding, etc.); and secondly, because of the progressive deterioration that buildings experience over time, which makes them more vulnerable to aggressive atmosphere. This latter point, however, can be rectified by maintenance and conservation of the buildings [44] and any repair work that has been carried out, consequently these aspects are not taken into account in this study.

The age of the 1816 buildings was determined and they were classified in accordance with the date they were built in the 5 periods set out in Section 4 , i.e. based on the different periods of expansion and crisis in the building sector: 1) 1968-1973; 2) 19731985; 3) 1985-1992; 4) 1992-1997; and 5) 1997-2007. The results are shown in percentages in Fig. 13.

It can be seen that towns such as Peñíscola, Benicàssim, Pobla de Farnals, El Perellonet, Cullera, Calpe and Playa de San Juan have a large proportion of buildings (between $25 \%$ and $50 \%$ ) that were built during the first period (1968-1973). Growth in the 
construction of buildings is also seen in the fifth period (1997-2007). During those years a large proportion of buildings were erected in the towns of Peñíscola, Oropesa del Mar, El Puig, Port Saplaya, Tavernes de la Valldigna, Calpe (between 20\% and 30\%) and, particularly, in Moncofa (nearly 70\%).

It can be concluded that the age of the buildings is significant in Benicàssim, Pobla de Farnals, El Perellonet, Cullera and La Playa de San Juan.

\subsection{Urban growth in the towns}

As seen in Section 3, another key aspect to be taken into account in calculating the level of exposure to the marine environment of buildings on the coast is the type of urban growth. To gauge its influence, we have differentiated between the following types of urban development:

- Expansion district development. This happened in coastal towns with a traditional historic centre, or, alternatively, in later expansions of the town towards the coast. The buildings are lined up together in perimeter blocks, creating a closed unit, with large fronts and compact in volume. They have shared walls, with one or several of their sides very much exposed to the sea spray.

- Linear development. This is defined by the characteristics of the beach, in its linear elongation. This type of growth is characterised by the existence of rectangular plots, generally parallel to the coast line. Within these plots the buildings do not follow any defined pattern. They are very high (over 10 storeys) standing on their own and have large common areas. This is the type of growth that predominates, above all, in areas away from the traditional historic centre. 
- Development adapted to the coast. This occurs in the coastal area where there are inlets and peninsulas or in zones where the hilly coastal area is rocky. There is a predominance of buildings in irregular blocks conforming to the shape of the hilly areas. They are very high and compact on account of the hills that make it difficult to make use of all the land, which leads to an accumulation of buildings on the beach-front.

- Holyday resort complexes. This has occurred in practically all the coastal towns, generally during the third and fourth period studied (1985-1992 and1992-1997). It is characterised by the construction of independent urban complexes on large plots with large common areas and terraced buildings or linear blocks of varying height.

These divisions make it possible to classify the urban growth according to the predominant type of development. Accordingly, in Fig. 14 the percentages are displayed for each of urban growth in the towns studied.

There is a high proportion of linear development in all the towns studied, except in Moncofa and Port Saplaya, where the expansion district development is predominant. Moncofa has grown as a traditional-type urban centre, with development in perimeter blocks, while Port Saplaya developed from the yacht marina that shapes the structure of the urban settlement.

Towns like Oropesa del Mar, Cullera and Calpe have a large proportion of development adapted to the coast. In contrast to them, there are the towns of Playa de San Juan, Benicassim, Xeraco, El Puig and Pobla de Farnals, where the linear development is predominant.

After the linear development, the most common type in the places studied is the 
expansion district development. In the towns of Peñíscola, Torreblanca, Cullera and Calpe, near the coastline, the traditional centre exists alongside holiday homes. The expansion district development, with its perimeter blocks increases the windbreak effect created by the buildings on the seafront.

Development adapted to the coast has only occurred in the towns of Oropesa, Cullera and Calpe, on account of their particular mountainous terrain.

The holyday resort complexes were built mainly during the most recent periods of urban expansion (1985-1992 and 1997-2007). They appear in towns like Peñíscola, Oropesa del Mar, Benicassim and Xeraco, the most affected by the important urban growth that took place during those years.

\subsection{Summary of the results of the factors studied}

This work has defined the factors that are most involved in the exposure of buildings on Valencia coast to the marine environment, i.e. the factors that have an important influence on the RC building structures damage caused by such environment. The characteristics of these factors have been studied in 14 towns on Valencia coast which are considered to be representative of the whole of the area.

The most significant characteristics of the study carried out are the following:

(1) Apartment blocks are the predominant type of building.

(2) Construction of the buildings was mostly begun at the end of the 1960 s and coincided with the building expansion development periods.

(3) The structure most widely used for such buildings was RC. Depending on the building practices of the different places, the following were used: bays 
with beams or wide flat beams, one-way and two-way reinforced slabs and precast or cast in place reinforced or pre-stressed joists.

(4) The characteristics of the RC are dependent on the date of construction and the technological level of the time and the regulations then in force.

(5) Protection of the buildings' RC is in general deficient due to:

a. the large degree of exposure due to the form of the buildings (large terraces, open ground floors, etc.);

b. the particular characteristics of the type of construction; and above all, the small amount of protection given to the slab fronts;

c. the small amount of covering provided for the reinforcement, particularly in buildings erected prior to 1988 , which was no more than $30 \mathrm{~mm}$.

(6) The environmental conditions that have most influence, in order of importance, are as follows:

a. the prevailing wind regime, especially if the winds exceed 10.80 $\mathrm{km} / \mathrm{h}$;

b. the precipitation regime and the wetting-drying cycles of the RC;

c. the variation in temperatures, though this has a lesser influence.

(7) The conditions of the urban environment that have greatest influence, in order of importance, are:

a. distance from the coast (above or below $100 \mathrm{~m}$ );

b. location relative to the beach, on the frontline or further back;

c. urban morphology (apartment blocks in open area or perimeter blocks); 
d. urban development type experienced in the area.

The combined effect of these factors determines the greater or lesser effect of the marine environment on RC structures in buildings situated on the coast. Table 2 shows a summary of the characteristics of each town in relation to these factors.

\section{Conclusions and future research}

The predominant buildings on Valencia coast are apartment blocks that have characteristics that make them very liable to suffer significant damage to their RC structures due to their exposure to the marine environment.

There are, however, no specific regulations governing the urban layout of buildings and their dimensions in relation to the factors that determine their degree of exposure to the aggressive marine environment, such as the specific environmental conditions (prevailing winds, temperature and rainfall regimes, etc.), urban factors (distance from the coastline, dimensions of buildings, etc.) or construction factors (type of cement, claddings, etc.). Conversely, in urban development the aspects that have traditionally played a dominant role were land use and property development, rather than any considerations for protecting buildings and their structures from the marine environment.

The construction characteristics for buildings situated near to the coast have always been determined by the construction practices and general codes in force at that time. Nevertheless, no specific construction regulations were given until 1988 with the EH-88 code.

The foregoing shows the need to draw up a model for determining or predicting the 
damage that the RC buildings structures in the towns on Valencia coast can suffer, given both the general and the particular characteristics of each town.

In order to draw up this model, it will first be necessary to determine the factors to be included together with the greater or lesser degree of importance and weighting of those factors in the model's mathematical formula.

These factors are those that have been defined and studied in this work on 14 towns on Valencia coast. From these data it will be possible to determine the level of aggressiveness of the environment of a town by using these factors, i.e., it will be possible to define its vulnerability to the marine environment.

\section{References}

[1] J.M. Adam, J.D. Moreno, M. Bonilla, T.M. Pellicer, Classification of damage to the structures of buildings in towns in coastal areas, Eng. Fail. Anal. 70 (2016) 212-221. doi:10.1016/j.engfailanal.2016.09.004.

[2] E.M. Obiol Menero, M.D. Pitarch Garrido, El litoral turístico valenciano. intereses y controversias en un territorio tensionado por el residencialismo, Bol. La Asoc. Geogr. Esp. (2011) 177-200.

[3] G. Rudilla, Doce Localidades costeras superan los 100.000 habitantes en Verano. http://www.abc.es/hemeroteca/historico-27-08-2007/abc/Valencia/docelocalidades-costeras-superan-los-100000-habitantes-enverano_164532275925.html, 27.08.2007 (accessed 27.03.17).

[4] J.D. Moreno, M. Bonilla, J.M. Adam, M. Victoria Borrachero, L. Soriano, Determining corrosion levels in the reinforcement rebars of buildings in coastal areas. A case study in the Mediterranean coastline, Constr. Build. Mater. 100 (2015) 11-21. doi:10.1016/j.conbuildmat.2015.09.059.

[5] ACI Committee 222 Report, Protection of Metals in concrete against corrosion, in: American Concrete Institute: Manual of Concrete Practice. Part 1: Materials 
and General Properties of Concrete, Detroit, 2002.

[6] U. Angst, B. Elsener, C.K. Larsen, ??ystein Vennesland, Critical chloride content in reinforced concrete - A review, Cem. Concr. Res. 39 (2009) 1122-1138. doi:10.1016/j.cemconres.2009.08.006.

[7] A. Costa, J. Appleton, Chloride penetration into concrete in marine environment Part I: Main parameters affecting chloride penetration, Mater. Struct. Constr. 32 (1999) 252-259. doi:10.1007/BF02479627.

[8] R. Liu, L. Jiang, J. Xu, C. Xiong, Z. Song, Influence of carbonation on chlorideinduced reinforcement corrosion in simulated concrete pore solutions, Constr. Build. Mater. 56 (2014) 16-20. doi:10.1016/j.conbuildmat.2014.01.030.

[9] X. Shi, N. Xie, K. Fortune, J. Gong, Durability of steel reinforced concrete in chloride environments: An overview, Constr. Build. Mater. 30 (2012) 125-138. doi:10.1016/j.conbuildmat.2011.12.038.

[10] H.S. Al-Alaily, A.A.A. Hassan, Time-dependence of chloride diffusion for concrete containing metakaolin, J. Build. Eng. 7 (2016) 159-169. doi:10.1016/j.jobe.2016.06.003.

[11] B. Pradhan, Corrosion behavior of steel reinforcement in concrete exposed to composite chloride-sulfate environment, Constr. Build. Mater. 72 (2014) 398410. doi:10.1016/j.conbuildmat.2014.09.026.

[12] Z. Jin, X. Zhao, T. Zhao, Y. Liu, Corrosion Behavior of Steel Bar and Corrosive Cracking of Concrete Induced by Magnesium-Sulfate-Chloride Ions, J. Adv. Concr. Technol. 14 (2016) 172-182. doi:10.3151/jact.14.172.

[13] R.R. Aveldaño, N.F. Ortega, Characterization of concrete cracking due to corrosion of reinforcements in different environments, Constr. Build. Mater. 25 (2011) 630-637. doi:10.1016/j.conbuildmat.2010.07.029.

[14] G.R. Meira, C. Andrade, E.O. Vilar, K.D. Nery, Analysis of chloride threshold from laboratory and field experiments in marine atmosphere zone, Constr. Build. Mater. 55 (2014) 289-298. doi:10.1016/j.conbuildmat.2014.01.052.

[15] C. Andrade, C. Alonso, On-site measurements of corrosion rate of 
reinforcements, Constr. Build. Mater. 15 (2001) 141-145. doi:10.1016/S09500618(00)00063-5.

[16] S.W. Tang, Y. Yao, C. Andrade, Z.J. Li, Recent durability studies on concrete structure, Cem. Concr. Res. $78 \quad$ (2015) 143-154. doi:10.1016/j.cemconres.2015.05.021.

[17] A.K. Lal, Making concrete structures more corrosion resistant, Build. Res. Inf. 20 (1992) 176-184. doi:10.1080/09613219208727203.

[18] M.E.R. Gustafsson, L.G. Franzén, Dry deposition and concentration of marine aerosols in a coastal area, SW Sweden, Atmos. Environ. 30 (1996) 977-989. doi:10.1016/1352-2310(95)00355-X.

[19] G.R. Meira, C. Andrade, C. Alonso, I.J. Padaratz, J.C. Borba, Modelling sea-salt transport and deposition in marine atmosphere zone - A tool for corrosion studies, Corros. Sci. 50 (2008). doi:10.1016/j.corsci.2008.06.028.

[20] G.R. Meira, W.T.A. Pinto, E.E.P. Lima, C. Andrade, Vertical distribution of marine aerosol salinity in a Brazilian coastal area - The influence of wind speed and the impact on chloride accumulation into concrete, Constr. Build. Mater. 135 (2017) 287-296. doi:10.1016/j.conbuildmat.2016.12.181.

[21] S. Rivero, B. Chico, D. De Fuente, M. Morcillo, Corrosión atmosférica del acero bajo en carbono en un ambiente marino polar. Estudio del efecto del régimen de vientos, Rev. Metal. 43 (2007) 370-383.

[22] M. Morcillo, B. Chico, L. Mariaca, E. Otero, Salinity in marine atmospheric corrosion: its dependence on the wind regime existing in the site, Corros. Sci. 42 (2000) 91-104. doi:10.1016/S0010-938X(99)00048-7.

[23] J.W. Fitzgerald, Marine aerosols: A review, Atmos. Environ. Part A. Gen. Top. 25 (1991) 533-545. doi:10.1016/0960-1686(91)90050-H.

[24] Y.A.V. Zaccardi, A. Bértora, A.A. Di Maio, Temperature and humidity influences on the on-site active marine corrosion of reinforced concrete elements, Mater. Struct. 46 (2013) 1527-1535. doi:10.1617/s11527-012-9994-z.

[25] V. Bouteiller, J. Cherrier, V.L. Hostis, Influence of humidity and temperature on 
the corrosion of reinforced concrete prisms, Eur. J. Environ. Civ. Eng. 16 (2012) 471-480. doi:10.1080/19648189.2012.668004.

[26] S.P. Karthick, A. Madhavamayandi, S. Muralidharan, V. Saraswathy, Electrochemical process to improve the durability of concrete structures, J. Build. Eng. 7 (2016) 273-280. doi:10.1016/j.jobe.2016.07.005.

[27] P. Sandberg, Chloride initiated reinforcement corrosion in marine concrete, Lund, Sweden, 1998. http://portal.research.lu.se/portal/en/publications/chlorideinitiated-reinforcement-corrosion-in-marine-concrete(737d1ae3-cf63-417f-89deac5e3a92a1ae).html.

[28] C. Andrade, A. Castillo, Evolution of reinforcement corrosion due to climatic variations, Mater. Corros. 54 (2003) 379-386. doi:10.1002/maco.200390087.

[29] M.H.F. Medeiros, A. Gobbi, G.C. Réus, P. Helene, Reinforced concrete in marine environment: Effect of wetting and drying cycles, height and positioning in relation to the sea shore, Constr. Build. Mater. 44 (2013) 452-457. doi:10.1016/j.conbuildmat.2013.02.078.

[30] Ley de 12 de mayo de 1956 sobre Régimen del suelo y ordenación urbana. BOE no. 135, May 14, 1956, 3106-3134. Jefatura del Estado, Madrid, 1956. https://www.boe.es/buscar/doc.php?id=BOE-A-1956-7013

[31] J. Pecourt, J.L Piñón, La Valencia marítima del 2000. Estudio del frente marítimo desde Sagunt hasta Cullera, COACV, Valencia, 1997.

[32] COPUT Conselleria d'Obres Públiques Urbanisme i Transports de la Generalitat Valenciana (Actualmente denominada Conselleria d'Habitage, Obres Públiques i Vertebració del Territori). Inspecciones realizadas por la Dirección General de Arquitectura y Vivienda, COPUT Data, 2015. http: http://www.gva.es.

[33] APTA Asociación para la Promoción Técnica del Acero, Análisis comparativo de soluciones estructurales y constructivas con productos siderúrgicos y de hormigón en las edificaciones, Madrid, 2006.

http://www.apta.com.es/pdf/edificacion_industrial.pdf

[34] IETCC Instituto Eduardo Torroja de la Construcción y el Cemento, Instrucción Especial para Estructuras de Hormigón Armado, Patronato Juan de la Cierva de 
Investigación Técnica del Consejo Superior de Investigaciones Científicas, Madrid, 1961.

[35] Decreto 2987/1968, de 20 de septiembre, por el que se aprueba la Instrucción para el proyecto y la ejecución de obras de hormigón en masa o armado (HA68), in BOE no. 290 de 3 de diciembre de 1968, 17257-17291, Presidencia del Gobierno, Madrid, 1968. https://www.boe.es/buscar/doc.php?id=BOE-A-19681406

[36] Decreto 3062/1973, de 19 de octubre, por el que se aprueba la Instrucción para el proyecto y la ejecución de obras de hormigón en masa o armado (EH-73), in BOE no. 293 de 7 de diciembre de 1973, 23701-24204, Presidencia del Gobierno, Madrid, 1973. https://www.boe.es/buscar/doc.php?id=BOE-A-19731694

[37] Real Decreto 824/1988, de 15 de julio, por el que se aprueba la Instrucción para el proyecto y la ejecución de obras de hormigón en masa o armado (EH-88) y la Instrucción para el proyecto y la ejecución de forjados unidireccionales de hormigón armado o pretensado (EF-88), in BOE no. 180, de 28 de julio de 1988, 23258-23295. Ministerio de Obras Públicas y Urbanismo, Madrid, 1988. https://www.boe.es/buscar/doc.php?id=BOE-A-1988-18670

[38] AEMET Agencia Estatal de Meteorología, Información meteorológica de las estaciones ubicadas en las provincias de Alicante, Castellón y Valencia, AEMET Data, 2015. http://www.aemet.es/serviciosclimaticos.

[39] IVIA Instituto Valenciano de Investigaciones Agrarias. Información sobre Datos meteorológicos, Servicio de Meteorología del Riego, IVIA Data, 2015, http://www.Xxxxx.com http://www.ivia.gva.es.

[40] A. Pérez Cueva, Atlas climático de la Comunidad Valenciana: (1961/1990), Conselleria d'Obres Públiques, Urbanisme i Transports. Valencia, 1994.

[41] CHJ Confederación Hidrográfica del Júcar, Mapas de peligrosidad de riesgo de inundaciones. Anexo, CHJ Data, 2014. http://www.chj.es/es-es/medioambiente/ [42] Ley 22/1988, 28 julio, de Costas, in BOE no. 181, July 29, 1988, 23386-23401. Texto consolidado 11 de diciembre de 2015. Jefatura del Estado, Madrid, 1988. https://www.boe.es/buscar/doc.php?id=BOE-A-1988-18762. 
[43] J.D. Moreno, Efecto del ambiente marino en edificios de segunda residencia en la costa valenciana. Influencia del crecimiento urbanístico y sistemas constructivos. Doctoral Dissertation. Universitat Politècnica de València, Valencia, 2016. https://riunet.upv.es/handle/10251/64088.

[44] C.Q. Li, Deterioration of concrete building structures, Build. Res. Inf. 25 (1997) 196-201. doi:10.1080/096132197370318. 

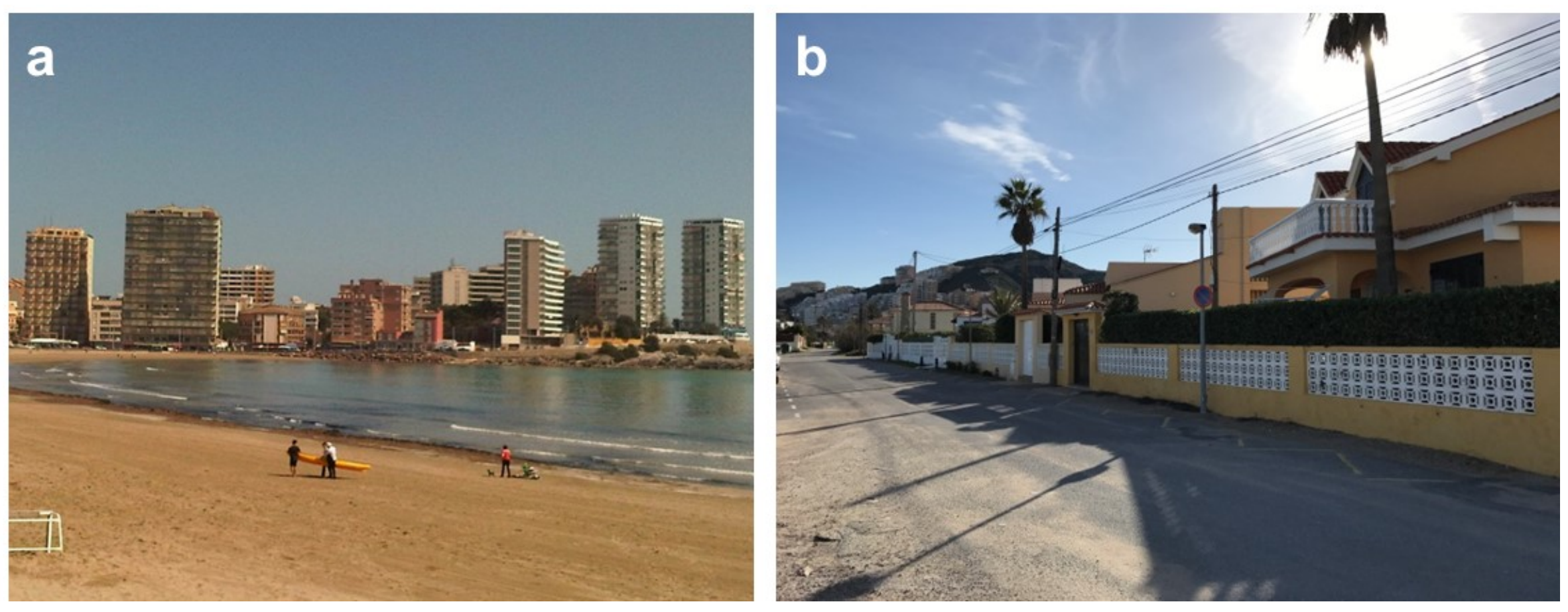

Fig. 1. Examples of building typologies in Valencia coast. a) Apartment blocks (Oropesa del Mar); b) Terraced houses (Cullera) 


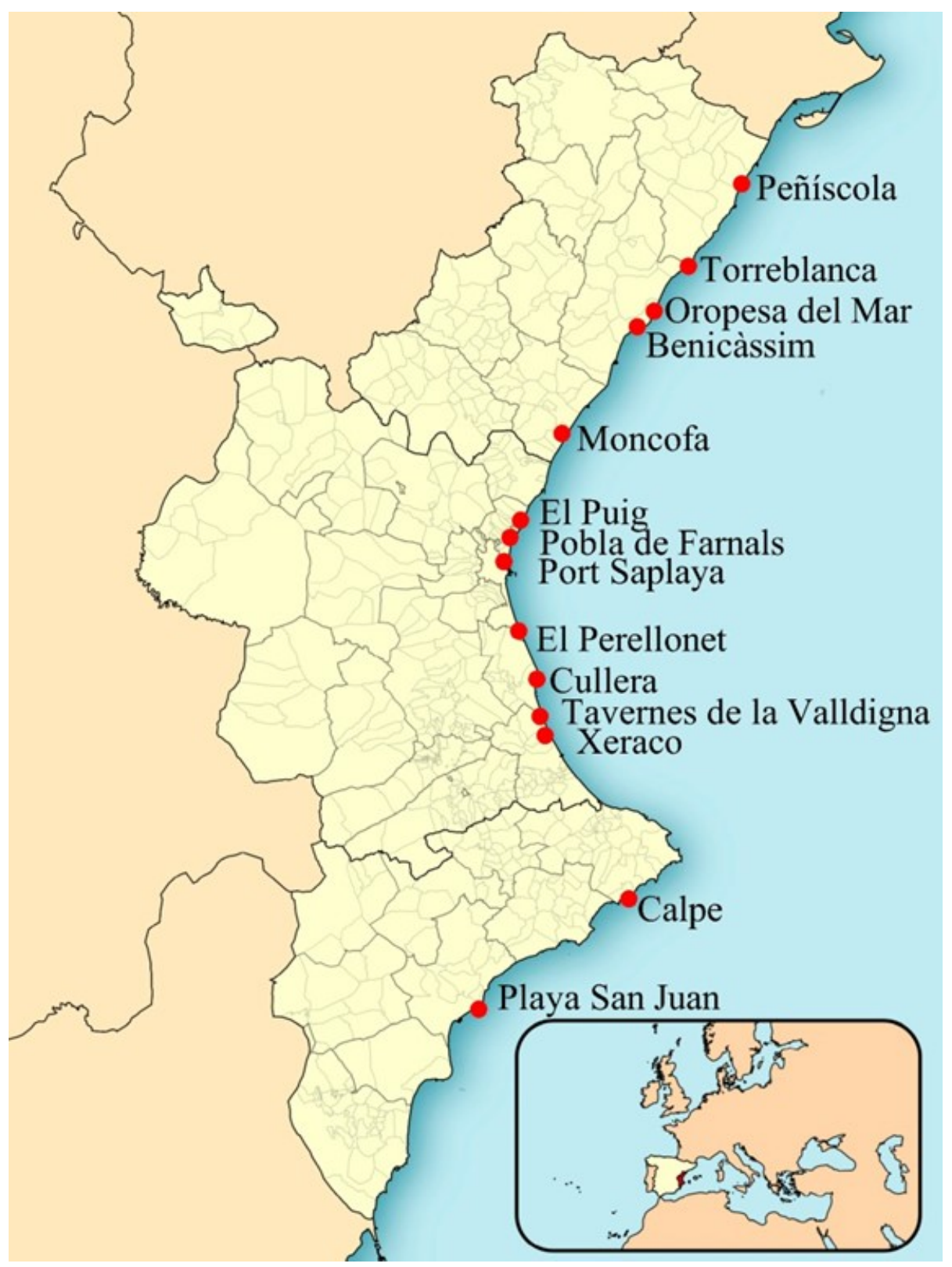

Fig. 2. Studied towns in Valencia coast 


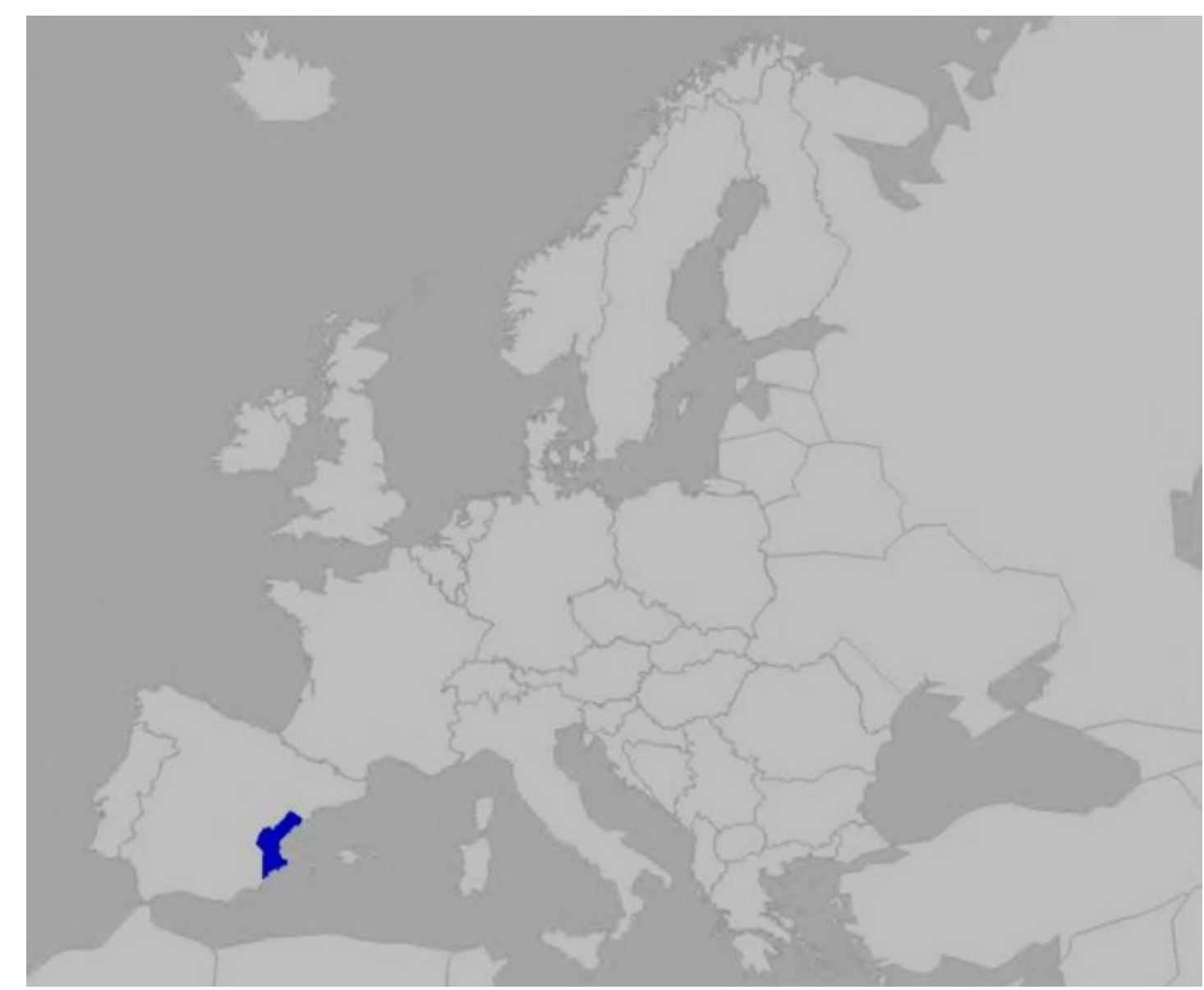

Fig. 3. Location of Valencia 

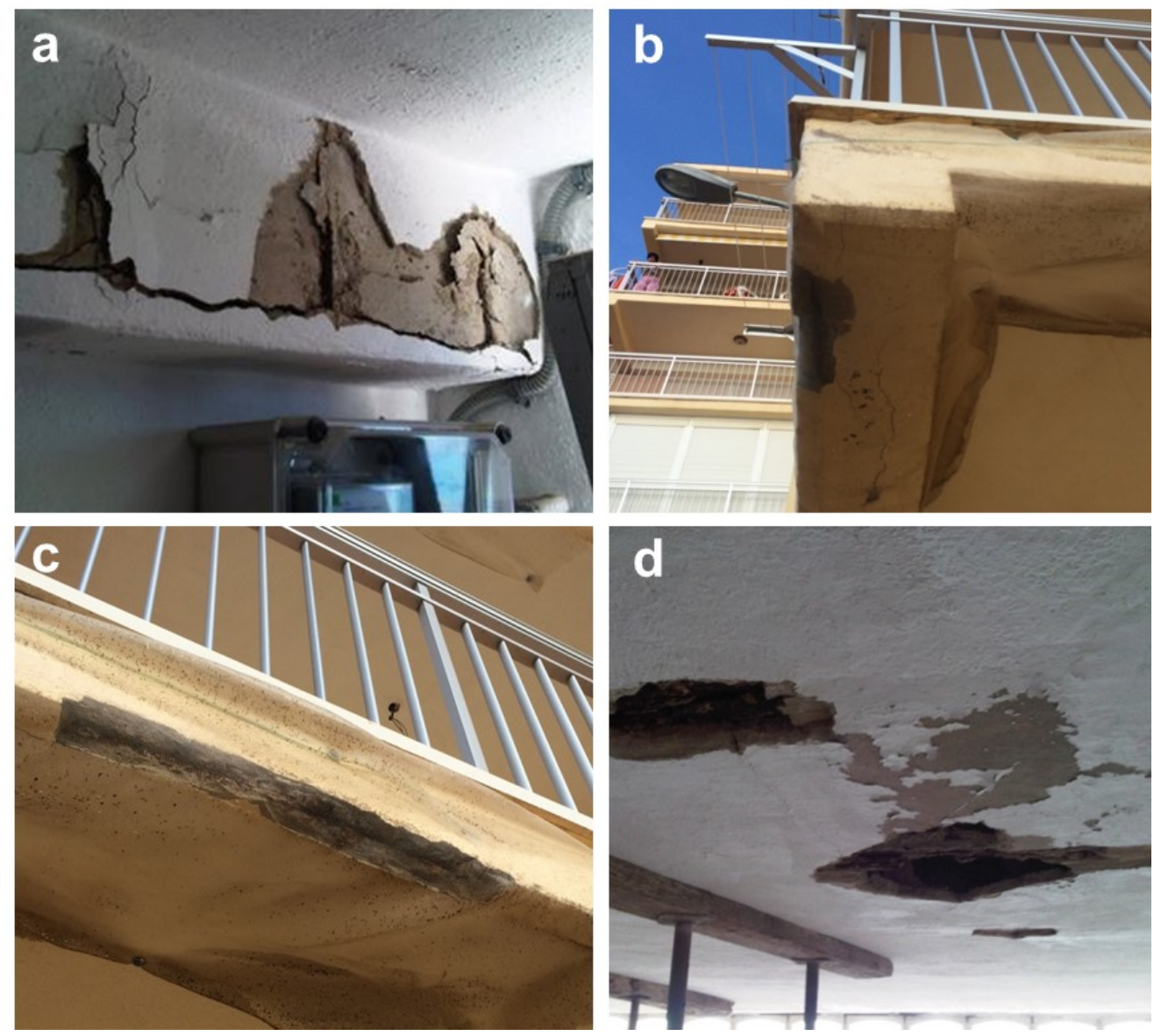

Fig. 4. Different damages in apartment buildings located in Valencia coast 
Other typologies $\quad$ Reinforced concrete structures $\quad$ Steel structures

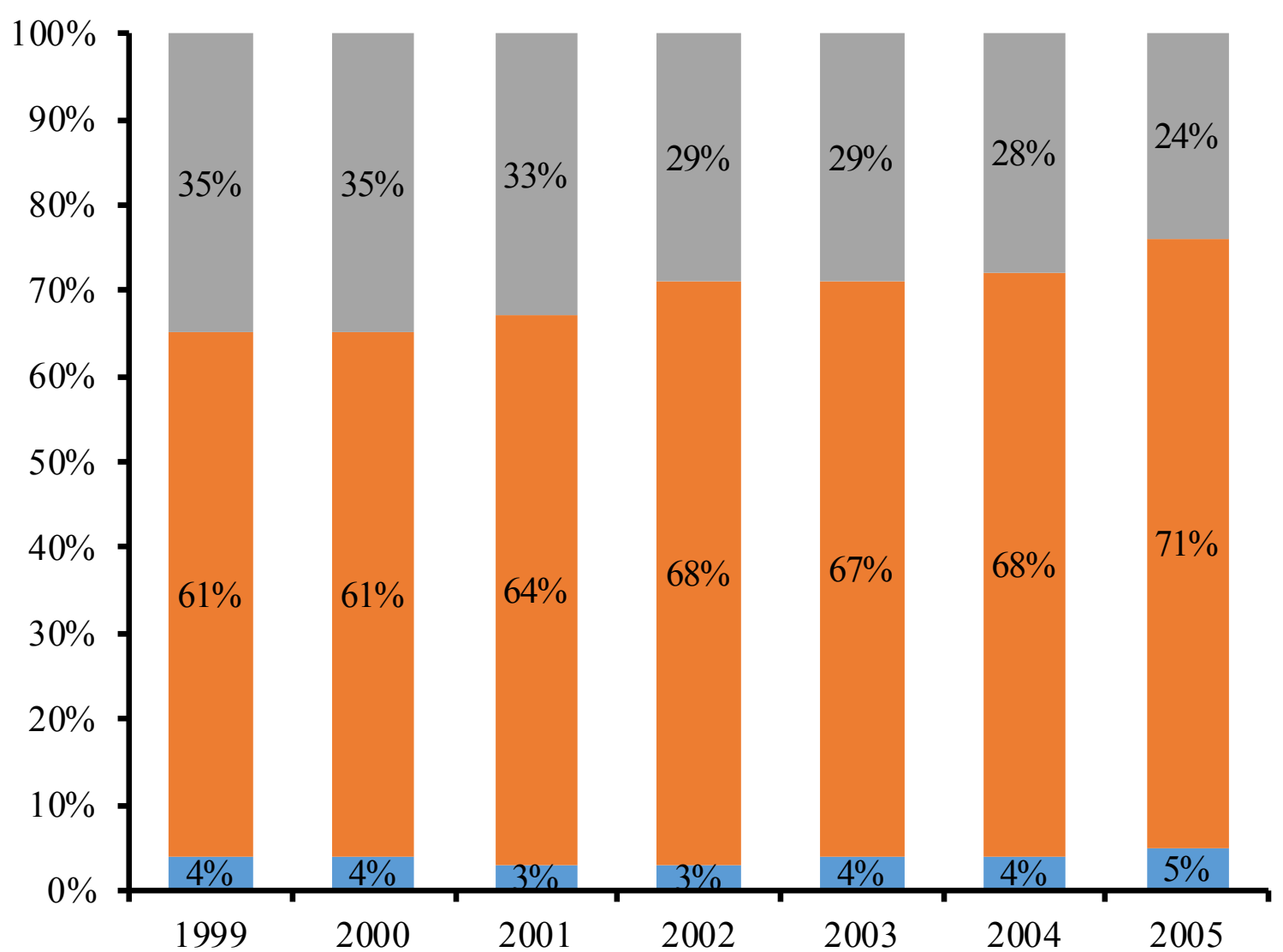

Fig. 5. Use of RC and steel in apartment building structures in the area, period 1999-2005 [33] 

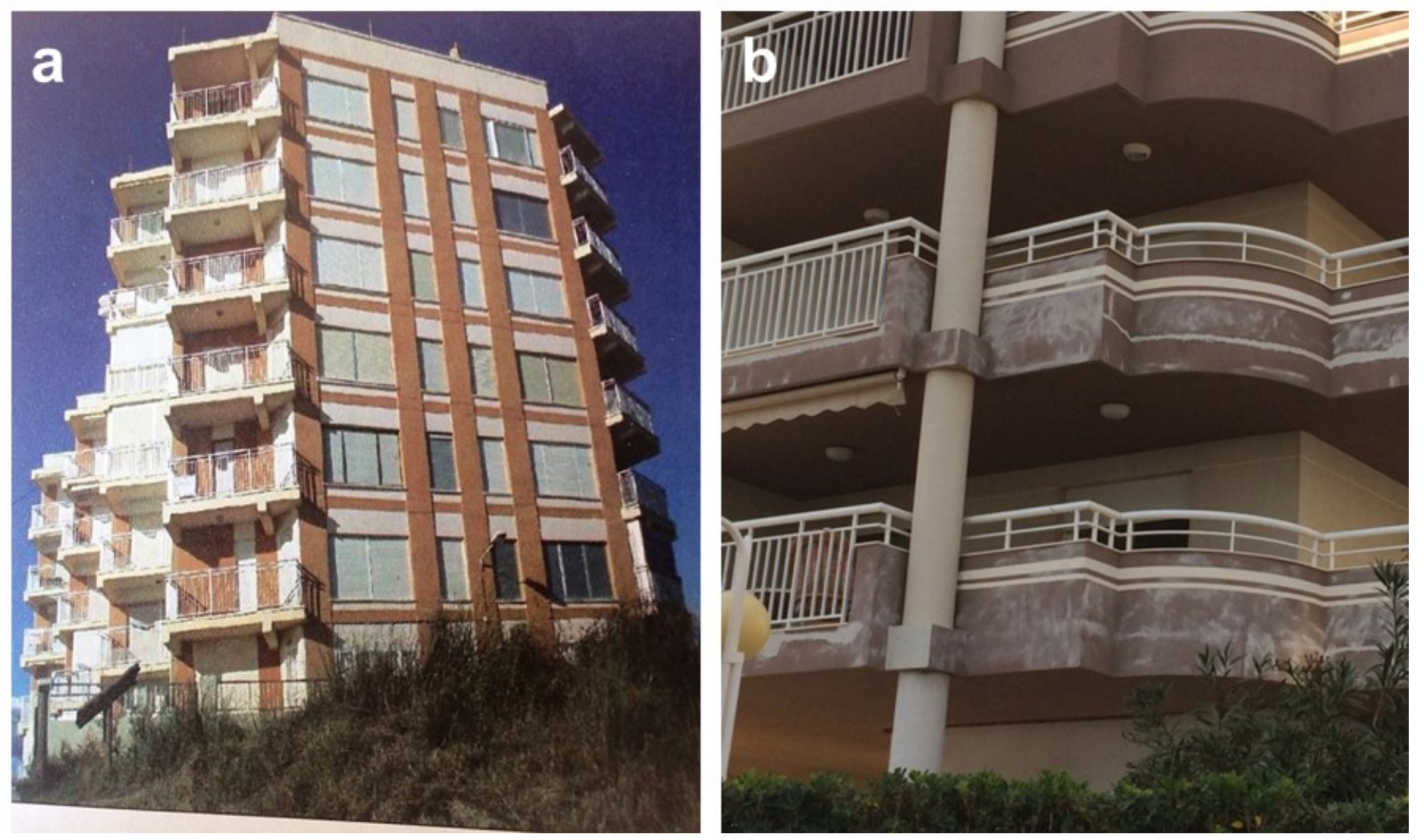

Fig. 6. a) Façade with mortar cladding, fronts of slabs, ledges and balcony beams with no protection (Cullera); b) Columns with painted cement-mortar rendering (Benicassim) 


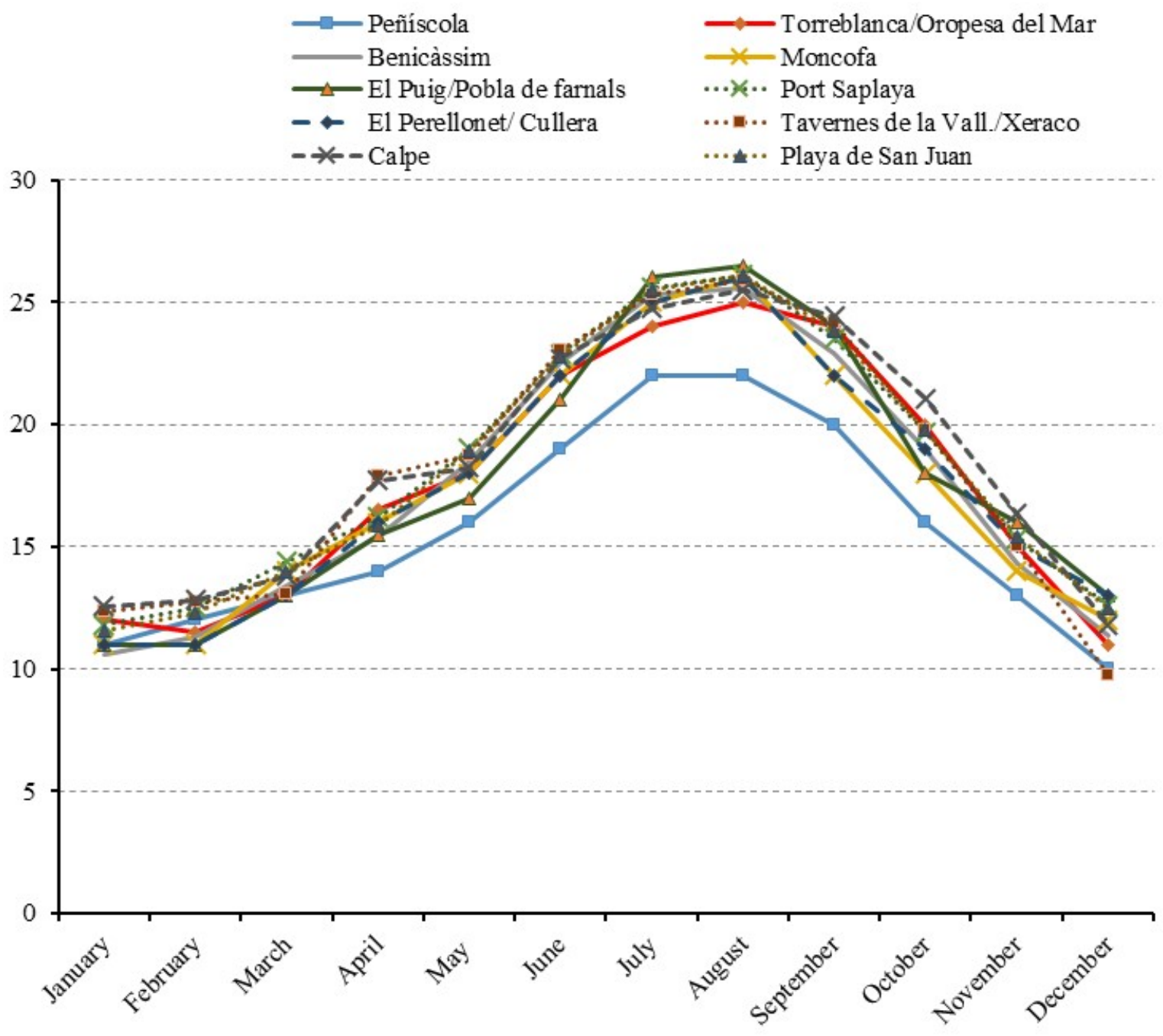

Note: The temperatures are represented in Celsius degrees

Fig. 7. Temperature regimen in the studied towns in the period 1981-2015 (adapted from IVIA data [39]) 


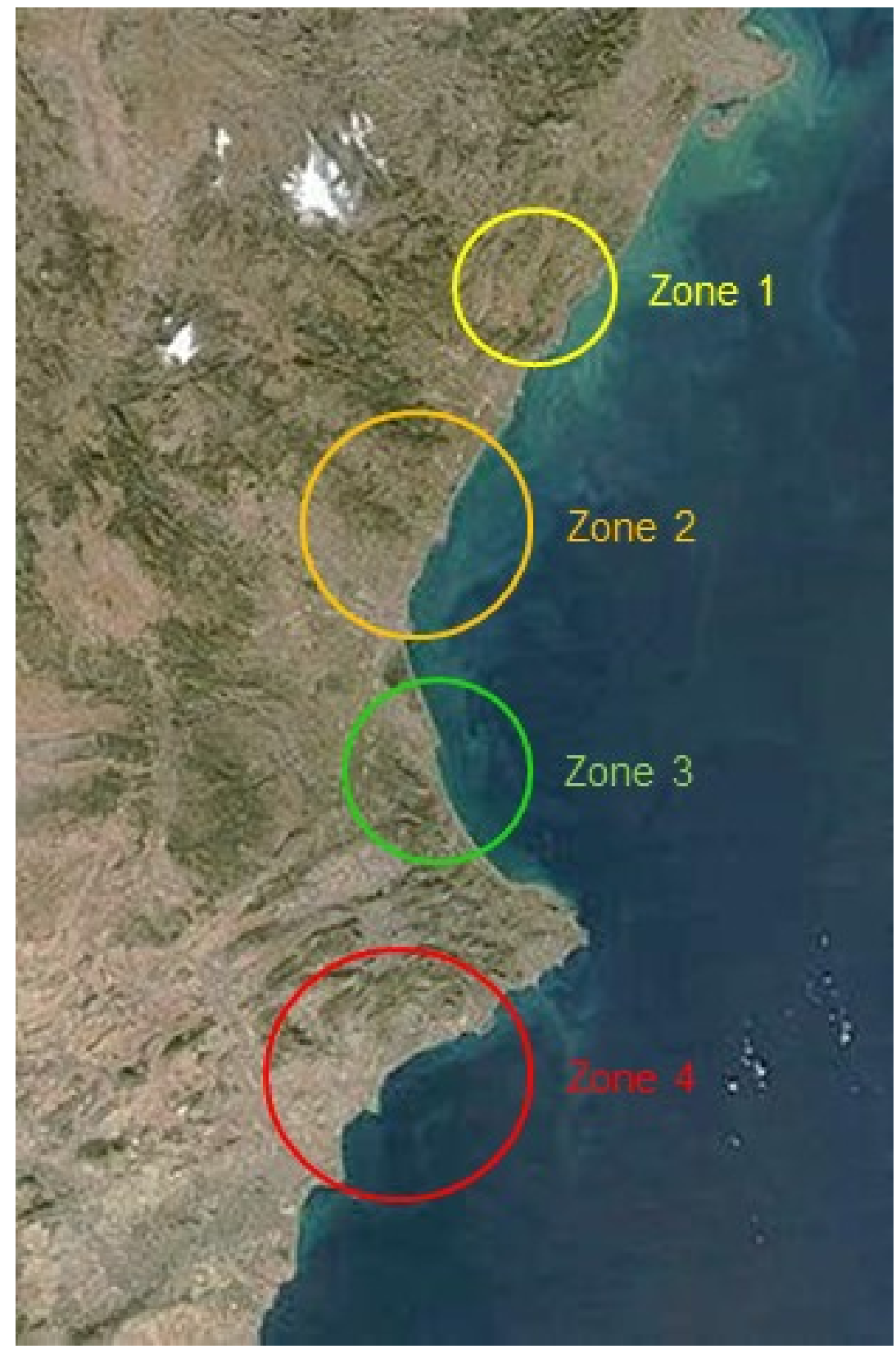

Fig. 8. Differentiation of zones in Valencia coast according to their precipitation regime 


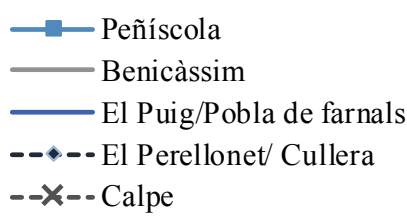

—— Torreblanca/Oropesa del Mar

$\leftarrow$ Moncofa

........ Port Saplaya

....... Tavernes de la Vall./Xeraco

........ Playa de San Juan

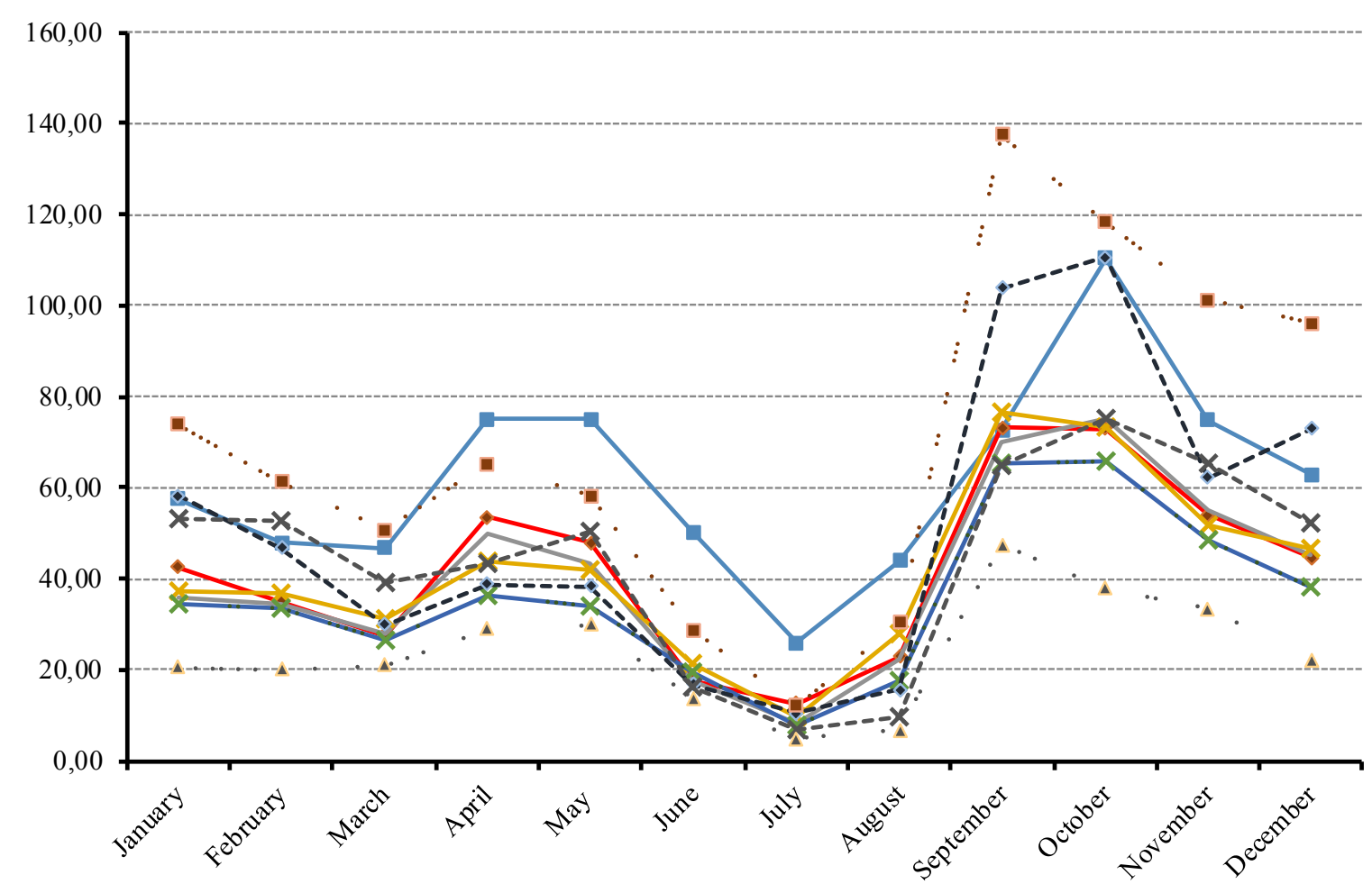

Note: Precipitation is represented in $\mathrm{mm}$

Fig. 9. Precipitation regime in the studied towns in the period 1981-2015 [38] 


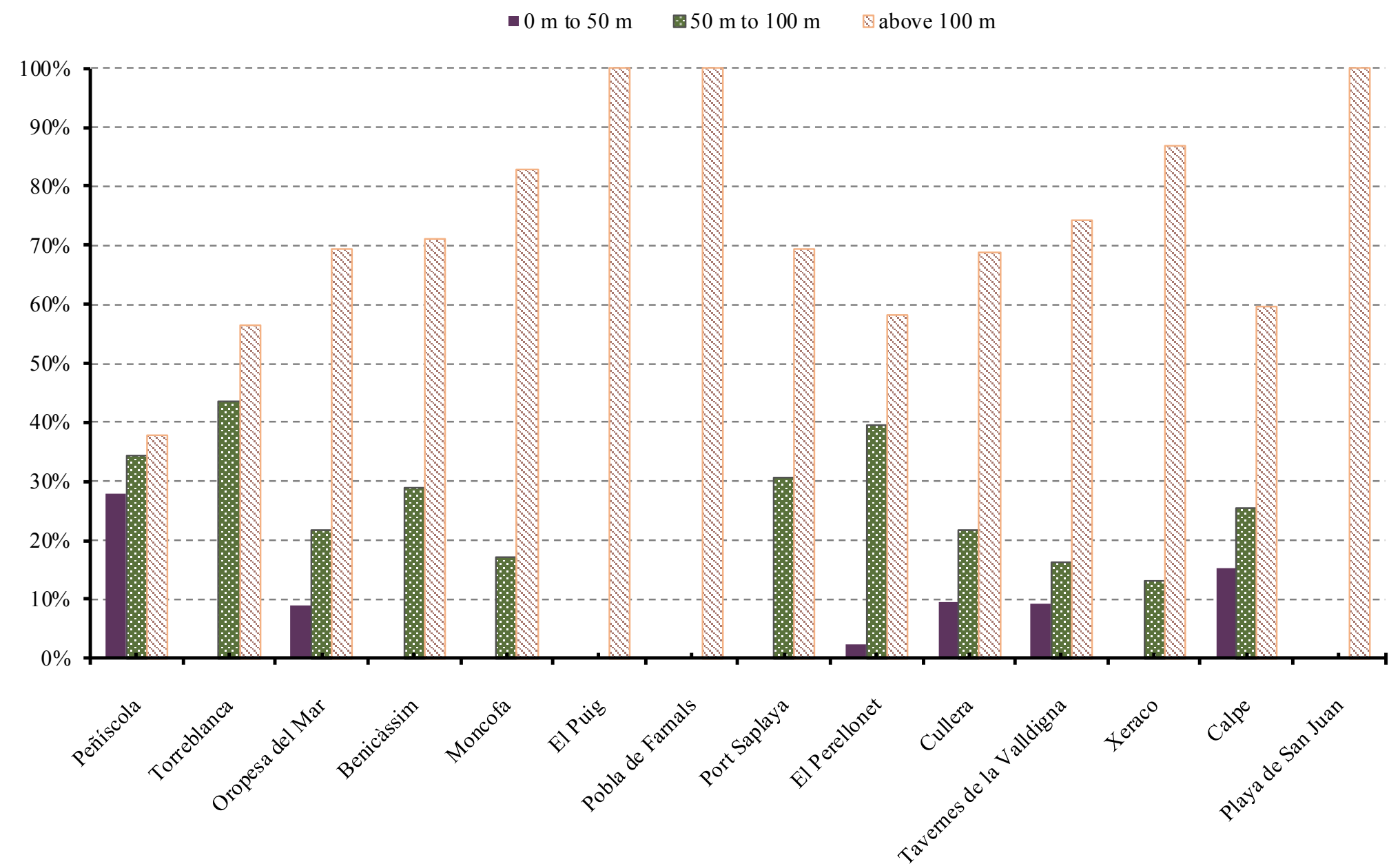

Fig. 10. Buildings located in the different strips of distance to the coast in the studied towns 


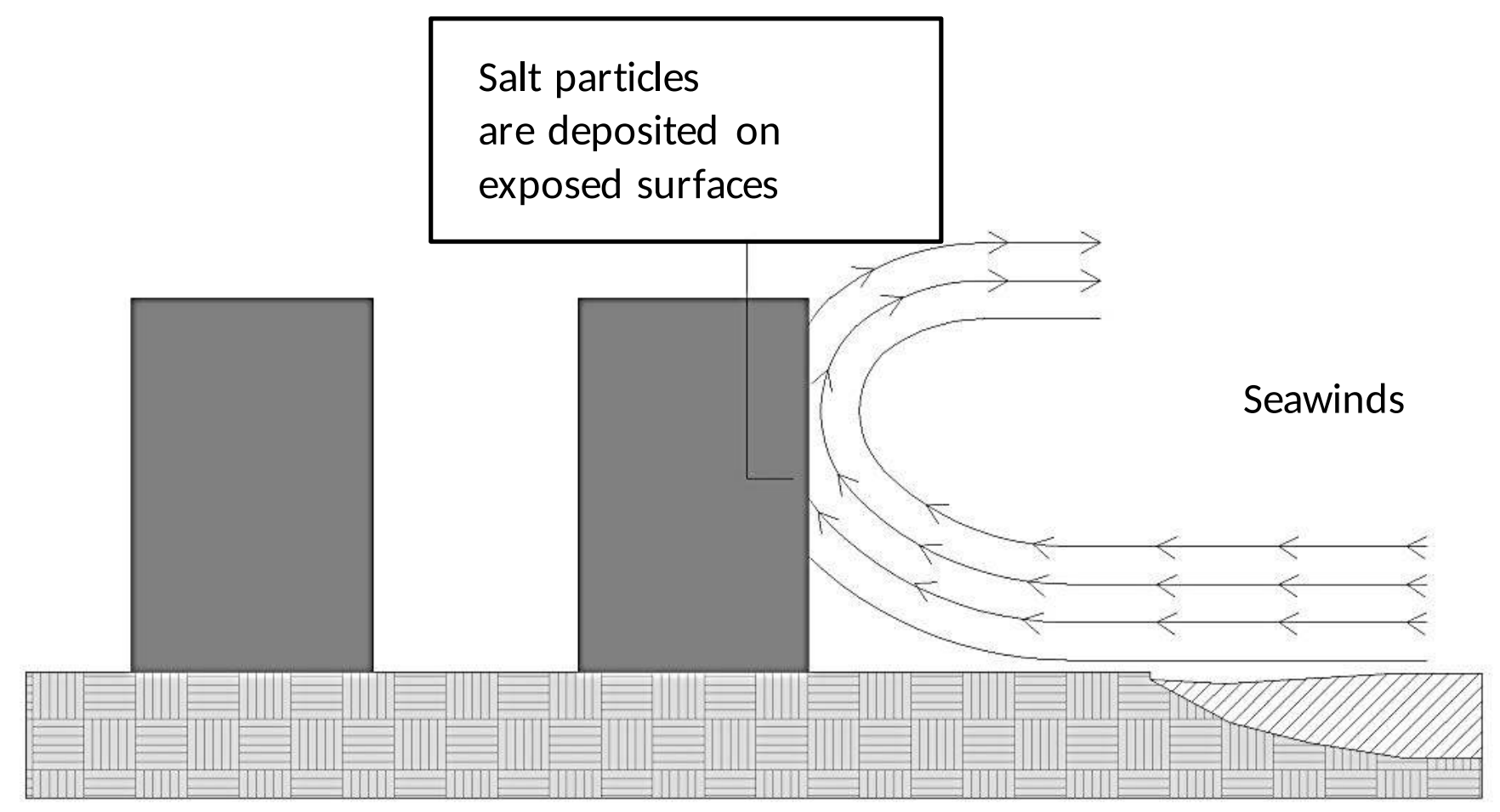

Fig. 11. Scheme of windbreak effect of buildings [43] 


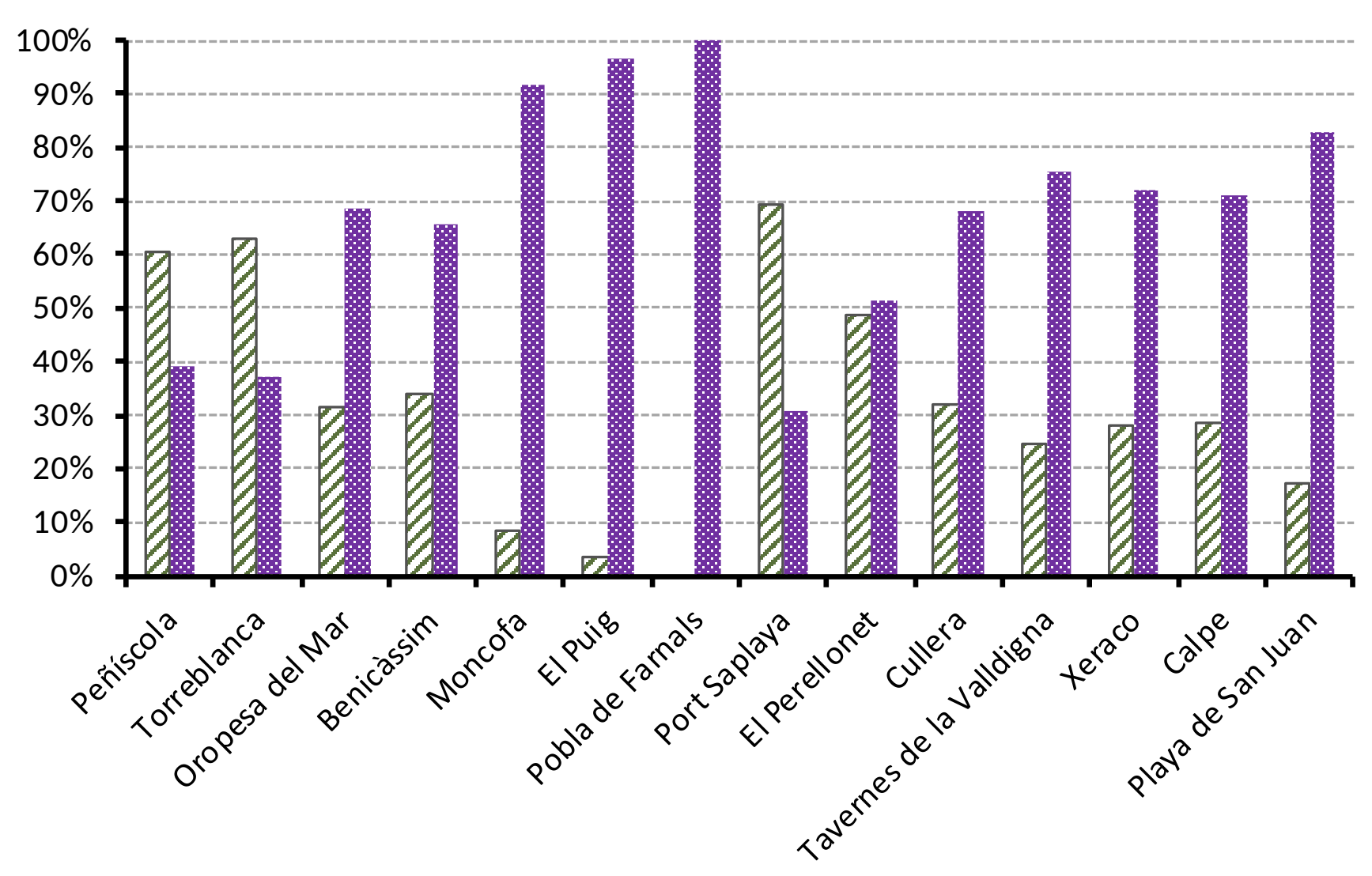

Fig. 12. Location of the apartment blocks in the studied towns: front line; second and other lines further back 
- First Period (1968-1973)

$\square$ Four Period (1992-1997)

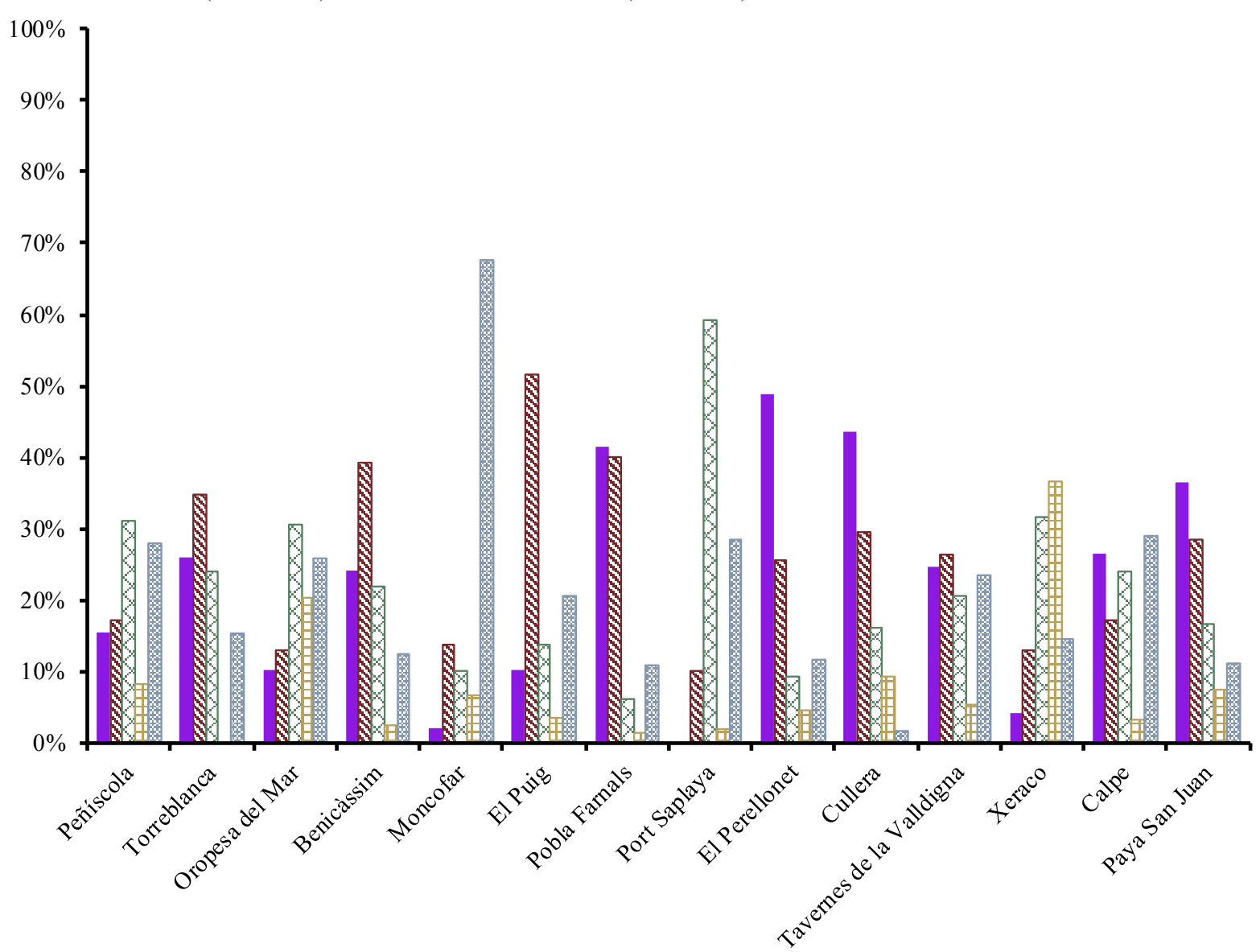

Fig. 13. Construction periods of apartment blocks in the studied towns $\square$ Second Period (1973-1985) $\quad \square$ Third Period (1985-1992) $\square$ Five Period (1997-2007) 


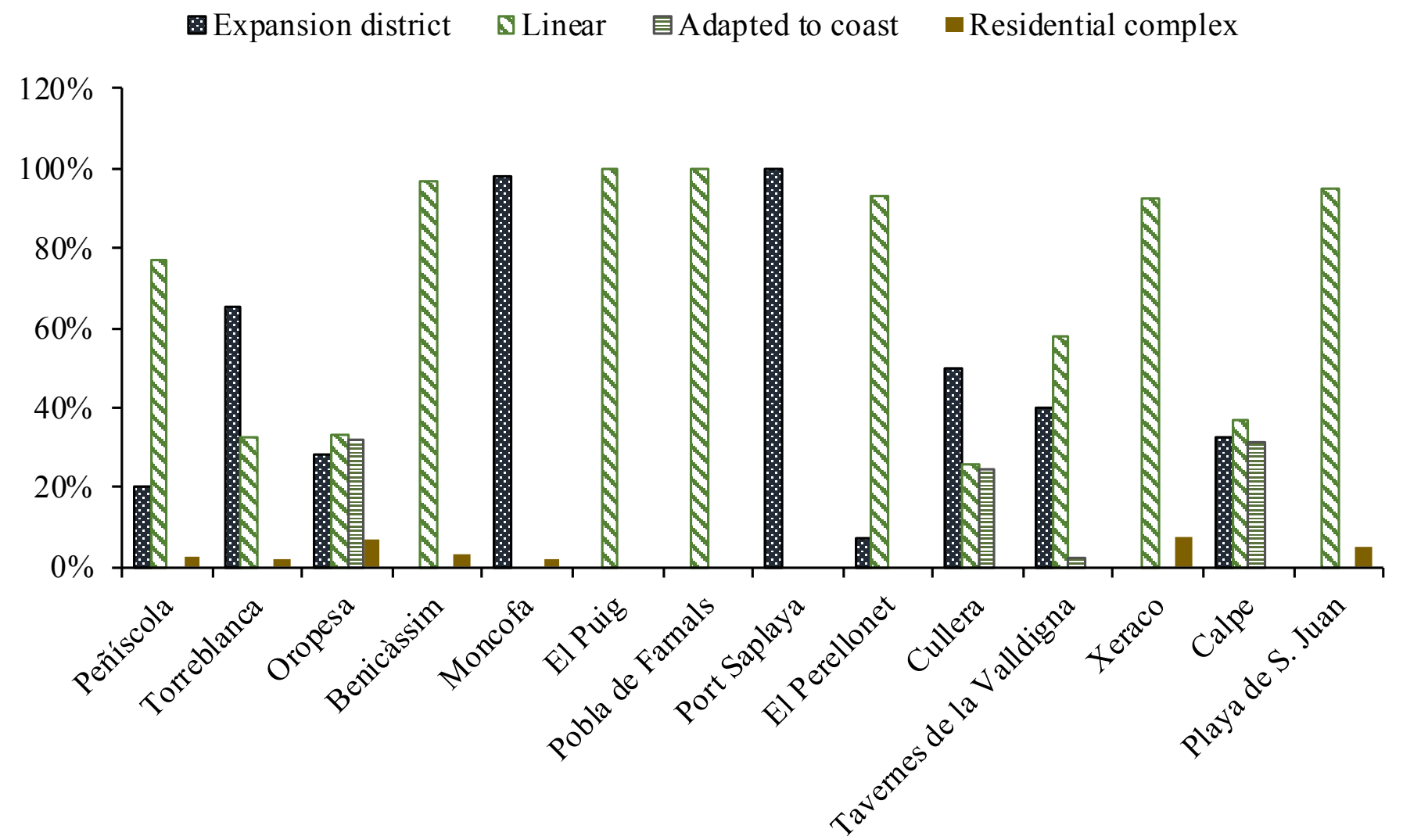

Fig. 14. Urban growth type of the apartment blocks in the studied towns 
Table 1. Prevailing winds coming from the sea and wind speed for that direction in the studied towns

\begin{tabular}{lccc}
\hline Coastal towns & $\begin{array}{r}\text { Prevailing } \\
\text { winds }\end{array}$ & $\begin{array}{r}\text { Maximum wind } \\
\text { speed }(\mathrm{km} / \mathrm{h})\end{array}$ & $\begin{array}{r}\text { Average wind } \\
\text { speed }(\mathrm{km} / \mathrm{h})\end{array}$ \\
\hline Peñíscola & E-SE & 12.00 & 10.00 \\
Torreblanca & S-SSE & 15.00 & 12.00 \\
Oropesa del Mar & S-SSE & 15.00 & 12.00 \\
Benicàssim & ESE & 12.50 & 8.50 \\
Moncofa & S-SE & 13.00 & 11.00 \\
El Puig & E-ENE & 9.00 & 7.00 \\
Pobla de Farnals & ESE & 13.00 & 10.00 \\
Port Saplaya & ESE & 13.00 & 10.00 \\
El Perellonet & S & 7.00 & 6.00 \\
Cullera & ENE & 9.00 & 7.00 \\
Tavernes de la Valldigna. & ENE & 9.00 & 7.00 \\
Xeraco & NE & 9.00 & 6.00 \\
Calpe & S-SW & 13.00 & 10.00 \\
Playa de San Juan & NE & 9.00 & 6.00 \\
\hline Notation: & & \\
- N-North: NNE-North-Northeast; NE-Northeast; ENE-East-Northeast & \\
- E-East: ESE-East-Southeast; SE-Southeast; SSE-South-Southeast & \\
- S-South: SSW-South-Southwest; SW-Southwest; WSW-West-Southwest & \\
- W-West; WNW-West-Northwest; NW-Northwest; NNW-North-Northwest & \\
\hline
\end{tabular}


Table 2. Main features of the studied towns

\begin{tabular}{|c|c|c|c|c|}
\hline Coastal towns & $\begin{array}{l}\text { Distance to } \\
\text { the seashore }\end{array}$ & $\begin{array}{l}\text { Location of } \\
\text { the buildings }\end{array}$ & Urban growth & Building periods \\
\hline Peñíscola & $\begin{array}{l}0 m-50 m \\
50 m-100 m\end{array}$ & $1^{\text {st }}$ line & Linear \& Expansion district & All periods \\
\hline Torreblanca & $50 \mathrm{~m}-100 \mathrm{~m}$ & $1^{\text {st }}$ line & Expansion district & All periods \\
\hline Oropesa del Mar & $\begin{array}{l}50 \mathrm{~m}-100 \mathrm{~m} \\
>100 \mathrm{~m}\end{array}$ & $2^{\text {nd }}$ line & Adapted to coast \& Linear & All periods \\
\hline Benicàssim & $50 \mathrm{~m}-100 \mathrm{~m}$ & $2^{\text {nd }}$ line & Linear & $1^{\text {st }} y 2^{\text {nd }}$ period \\
\hline Moncofa & $>100 \mathrm{~m}$ & $2^{\text {nd }}$ line & Expansion district & $5^{\text {th }}$ period \\
\hline El Puig & $>100 \mathrm{~m}$ & $2^{\text {nd }}$ line & Linear & $2^{\text {nd }}$ period \\
\hline Pobla de Farnals & $>100 \mathrm{~m}$ & $2^{\text {nd }}$ line & Linear & $1^{\text {st }}$ y $2^{\text {nd }}$ period \\
\hline Port Saplaya & $50 \mathrm{~m}-100 \mathrm{~m}$ & $1^{\text {st }}$ line & Expansion district & $3^{\text {rd }}$ y $5^{\text {th }}$ period \\
\hline El Perellonet & $50 \mathrm{~m}-100 \mathrm{~m}$ & $2^{\text {nd }}$ line & Linear & $1^{\text {st }}$ y $2^{\text {nd }}$ period \\
\hline Cullera & $0 m-50 m$ & $2^{\text {nd }}$ line & Expansion district & $1^{\text {st }} y 2^{\text {nd }}$ period \\
\hline Tavernes de la Valldigna & $>100 \mathrm{~m}$ & $2^{\text {nd }}$ line & Linear & All periods \\
\hline Xeraco & $>100 \mathrm{~m}$ & $2^{\text {nd }}$ line & Linear & $3^{\text {rd }} y 4^{\text {th }}$ period \\
\hline Calpe & $50 \mathrm{~m}-100 \mathrm{~m}$ & $2^{\text {nd }}$ line & Adapted to coast \& Linear & All periods \\
\hline Playa de San Juan & $>100 \mathrm{~m}$ & $2^{\text {nd }}$ line & Linear & $1^{\text {st }}$ y $2^{\text {nd }}$ period \\
\hline
\end{tabular}

